\title{
REVIEWS
}

\section{Paul E. Ceruzzi. Internet Alley: High Technology in Tysons Corner,}

1945-2005. ix+192 pp. Cambridge, MA: MIT Press, 2008. 7x9, 24 illus.

\author{
Isaac Record* and Andrew Munro ${ }^{+}$
}

Internet Alley is much more a book about regional history than about politics, economics, or history of technology, yet it draws extensively on all of these fields. The book is stronger for its interdisciplinarity, but as a result does not sit comfortably within any traditional historical discourse. Historians of science or technology not dealing with northern Virginia in the twentieth century will find little of help in this book.

In 1945, Tysons Corner was a dusty crossroads in dairy country. Today, it is a cluster of glassy high-tech office buildings set against upscale suburbia. It is the third largest aggregation of technology-related firms in the United States (after Silicon Valley and Boston's Route 128) and has become one of the key drivers of economic growth in North Virginia. Internet Alley is Ceruzzi's answer to the question, "Why Tysons Corner?" In seeking his answer, Ceruzzi melds aspects of politics, engineering, and geography.

During the Cold War, federal regional planners sought to disperse vital resources to minimize the potential damage of a nuclear strike on the Capital Region, resulting in the interstate highway system and the circumferential DC beltway. Tysons Corner is a crossroads of the beltway and the Dulles Airport Access Road, making it ideal for the formation of an Edge City. Ceruzzi does not rest his story on brute facts of geography; favourable zoning rules, entrepreneurial banks, and driven individual developers conditioned Tysons Corner to take advantage of the government monopsony on systems engineering-a fusion of operations research and computers-to become a repository for technical expertise outside of the Pentagon bureaucracy and highturnover military billets. The admixture of these and other contingent factors explains the development of Tysons Corner into Internet Alley, the physical site of five of the thirteen Internet root switchers.

It is a story worth telling, and Ceruzzi looks to personal interviews, public records, and traditional historical accounts in each of the disciplines he draws from. His narrative is straightforward; more worthwhile for its synthetic rather

\footnotetext{
${ }^{*}$ Isaac Record is a PhD candidate at the Institute for the History and Philosophy of Science at the University of Toronto. His research is focused on the question of how the adoption and use of scientific instruments-such as the computer-has constrained and shaped scientific practice.

${ }^{+}$Andrew Munro is a PhD Candidate at the Institute for the History and Philosophy of Science. His research investigates current and historical approaches to the commercialization of universitybased research and the role that innovation plays in national and regional economic growth policies.
}

Spontaneous Generations 2:1 (2008). ISSN 1913-0465. University of Toronto 
than analytic emphasis. The book is occasionally marred by distracting typographical errors (e.g., p. 210), and a book so focused on geography would be better-served by a larger, more detailed map-one befitting the book's large format, an opportunity apparently forgotten in the selection of some images. A more serious flaw in the book is its jumbled organization.

The structure of the book reflects its muddled disciplinary heritage: after a sweeping introduction, Ceruzzi alternates between a discussion of regional planning and a history of the engineering firms located in Tysons Corner (with disappointingly superficial attention to the engineering work itself), first in the period 1956-1964 and then 1965-1990. Ceruzzi organizes his chapters roughly chronologically, but each chapter highlights a key set of issues that contributed to the formation of the region. He weaves together the geopolitical and local factors that lead to several of the major defence- and science-related spending programs from the US Government and how local actors responded to the opportunities presented to them by these programs, leading to the region's unique development. The payoff of this meandering narrative is chapter 7, "Internet Alley," where Ceruzzi explains how Tysons Corner became the headquarters for so many high-tech and Internet-related firms.

In this chapter, which covers the transition in Tysons Corner from government contract operations research (the story of the previous six chapters) to private Internet telecommunications firms, Ceruzzi reconnects with the literature surrounding his best-known previous work: 1998's A History of Modern Computing. And it is here that Internet Alley begins to fit into a broader disciplinary history. While previous histories of the Internet have focused on technology, engineering, mathematics, its nascence in distributed defence or adolescence in counterculture values, or political challenges, Ceruzzi gives us a prehistory of the geography of the Internet-a valuable addition. As such, though, chapter 7 largely stands on its own; the previous 134 pages are subtext and do not present material necessary to advance the core arguments of the chapter.

After chapter 7, Ceruzzi draws the book to a close with a futurist reverie. The geography of Tysons Corner is a paradox. While a crossroads of the beltway and Dulles Airport Road made for a convenient edge city in an era that demanded distribution of infrastructure, today it seems to forecast its doom: people are moving to cities or suburbs and away from the edge city. Ceruzzi implicates transportation in this future, which is perhaps an unsurprising conclusion for the curator of the Smithsonian's National Air and Space Museum to reach.

Internet Alley is an odd amalgam of approaches, not unlike Tysons Corner itself. 
ISAAC RECORD

IHPST, University of Toronto

91 Charles St. West

Toronto, ON

Canada, M5S $1 \mathrm{~K} 7$

isaac.record@utoronto.ca

ANDREW MUNRO

IHPST, University of Toronto

91 Charles St. West

Toronto, ON

Canada, M5S 1K7

andrew.munro@utoronto.ca 